\title{
Topological estimation of cytotoxic activity of some anti-HIV agents: HEPT analogues
}

\author{
VIJAY K AGRAWAL ${ }^{1}$, KAMLESH MISHRA ${ }^{1}$, RUCHI SHARMA ${ }^{1}$ and P V KHADIKAR ${ }^{2} *$ \\ ${ }^{1}$ QSAR and Computer Chemical Laboratories, APS University, Rewa 486003 , India \\ ${ }^{2}$ Research Division, Laxmi Fumigation and Pest Control Pvt. Ltd., 3, Khatipura, Indore 452 007, India \\ e-mail: vijay-agrawal@lycos.com; pvkhadikar@rediffmail.com
}

MS received 2 June 2003; revised 20 December 2003

\begin{abstract}
QSAR studies on anti-HIV cytotoxic activities of a series of HEPT(1-[(2-hydroxyethoxy) methyl]-6-(phenylthio)-thymine) analogues have been discussed. The molecular descriptors used being van der Waals volume $(V w)$ and equalized electronegativity $\left(\chi_{\text {eq }}\right)$. The in vitro cytotoxicities $\left(p C C_{50}\right)$ were modelled using these parameters. It was observed that upon introduction of indicator parameters statistically excellent models are obtained. The predictive power of the models was examined using a cross-validation method.
\end{abstract}

Keywords. Anti-HIV agents; molecular modelling; van der Waals volume; cytotoxic activity; HEPT analogues; equalized electronegativity.

\section{Introduction}

The use of topological indices in modelling the toxicity of organic compounds is well known. ${ }^{1-4}$ Ofcourse, for modelling toxicity of chemicals one may employ molecular descriptors other than topological indices $^{5-10}$. In our earlier study ${ }^{11-13}$ we observed that the equalized electronegativity $\left(\chi_{\mathrm{eq}}\right),{ }^{14,15}$ van der Waals volume $(V w),{ }^{16}$ their combinations with each other and introduction of indicator parameters resulted in statistically excellent models. Such nontopological modelling appears to be interesting.

Reverse transcriptase (RT) plays a central role in the replication of HIV. A number of RT-inhibitors active against both HIV-1 and HIV-2 RT or only against HIV-1 RT have been discussed in the literature. ${ }^{1,2}$

The case of topological indices in modelling toxicity of organic compounds is well known., ${ }^{3,4}$ of course, for modelling toxicity of chemicals one may also employ molecular descriptors other than topological indices. ${ }^{5-10}$ In our earlier study ${ }^{11-13}$ we observed that equalized electronegativity ${ }^{14,15}\left(\chi_{\mathrm{eq}}\right)$, van der Waals volume ${ }^{16}(V w)$, their combinations with each other and introduction of indicator parameter(s) gave statistically significant models. The nontopological molecular descriptors gave fairly interesting results.

\footnotetext{
*For correspondence
}

In this paper we have, therefore, carried out quantitative structure-activity relationship (QSAR) analysis on a series of HEPT (1-[(2-hydroxyethoxy) methyl]-6-(phenylthio)-thymine) analogues for modelling their cytotoxic activity using van der Waals volume $(V w)$, equalized electronegativity $\left(\chi_{\text {eq }}\right)$ along with some indicator parameters. The details are given below. A series of 48 HEPT analogues as demonstrated in table 1 (figure 1) were used for this purpose.

The in vitro cytotoxicities $\left(p C C_{50}\right)$ needed for the study were adopted from the literature. ${ }^{3}$ The molecular descriptors, viz. equalized electronegativity $\left(\chi_{\text {eq }}\right)$, and van der Waals volume $(V w)$ were calculated using the procedure described in the subsequent sections. ${ }^{4-10}$ In addition, we have also used three dummy parameters (indicator parameters) $I p_{1}$, $I p_{2}$ and $I p_{3}$ related to substituents at $\mathrm{R}^{1}, \mathrm{R}^{2}$ and $\mathrm{R}^{4}$. Thus, we have a set of six molecular descriptors for modelling anti-HIV activity of 48 compounds in the present study. Our objective in the present study to determine which out of these six descriptors is useful in modelling the activity $\left(p C C_{50}\right)$.

\section{Methodology used}

\subsection{Toxicity data}

In vitro cytotoxicities $\left(p C C_{50}\right)$ were adopted from the literature. ${ }^{17}$ 
Table 1. Structural details and cytotoxic activity $\left(p C C_{50}\right)$ of the compounds (HEPT analogues) used in the present study.

\begin{tabular}{|c|c|c|c|c|c|c|c|c|}
\hline \multirow{3}{*}{$\begin{array}{l}\text { Compd. } \\
\text { No. }\end{array}$} & \multirow[b]{3}{*}{$X$} & \multirow[b]{3}{*}{$\mathrm{R}^{1}$} & \multirow[b]{3}{*}{$\mathrm{R}^{2}$} & \multirow[b]{3}{*}{$\mathrm{R}^{3}$} & \multirow[b]{3}{*}{$\mathrm{R}^{4}$} & \multicolumn{3}{|c|}{$p C C_{50}$} \\
\hline & & & & & & \multirow[b]{2}{*}{ Obs. } & \multicolumn{2}{|c|}{ Est. } \\
\hline & & & & & & & Model 3 & Model 4 \\
\hline 1 & $\mathrm{O}$ & $\mathrm{CH}_{2} \mathrm{CH}_{2} \mathrm{OH}$ & $\mathrm{Me}$ & $\mathrm{H}$ & $\mathrm{Me}$ & 2.623 & $2 \cdot 439$ & $2 \cdot 460$ \\
\hline 2 & $\mathrm{O}$ & $\mathrm{CH}_{2} \mathrm{CH}_{2} \mathrm{OH}$ & $\mathrm{Et}$ & $\mathrm{H}$ & $\mathrm{Me}$ & $2 \cdot 258$ & $2 \cdot 328$ & $2 \cdot 304$ \\
\hline 3 & $\mathrm{O}$ & $\mathrm{CH}_{2} \mathrm{CH}_{2} \mathrm{OH}$ & $t-\mathrm{Bu}$ & $\mathrm{H}$ & $\mathrm{Me}$ & 1.875 & $2 \cdot 108$ & $2 \cdot 016$ \\
\hline 4 & $\mathrm{O}$ & $\mathrm{CH}_{2} \mathrm{CH}_{2} \mathrm{OH}$ & $\mathrm{CH}_{2} \mathrm{OH}$ & $\mathrm{H}$ & $\mathrm{Me}$ & $2 \cdot 465$ & $2 \cdot 473$ & $2 \cdot 447$ \\
\hline 5 & $\mathrm{O}$ & $\mathrm{CH}_{2} \mathrm{CH}_{2} \mathrm{OH}$ & $\mathrm{CF}_{3}$ & $\mathrm{H}$ & $\mathrm{Me}$ & $2 \cdot 292$ & $2 \cdot 210$ & $2 \cdot 118$ \\
\hline 6 & $\mathrm{O}$ & $\mathrm{CH}_{2} \mathrm{CH}_{2} \mathrm{OH}$ & $\mathrm{F}$ & $\mathrm{H}$ & $\mathrm{Me}$ & $2 \cdot 450$ & $2 \cdot 321$ & $2 \cdot 286$ \\
\hline 7 & $\mathrm{O}$ & $\mathrm{CH}_{2} \mathrm{CH}_{2} \mathrm{OH}$ & $\mathrm{Cl}$ & $\mathrm{H}$ & $\mathrm{Me}$ & $2 \cdot 322$ & $2 \cdot 294$ & $2 \cdot 272$ \\
\hline 8 & $\mathrm{O}$ & $\mathrm{CH}_{2} \mathrm{CH}_{2} \mathrm{OH}$ & $\mathrm{Br}$ & $\mathrm{H}$ & $\mathrm{Me}$ & $2 \cdot 149$ & $2 \cdot 271$ & $2 \cdot 260$ \\
\hline 9 & $\mathrm{O}$ & $\mathrm{CH}_{2} \mathrm{CH}_{2} \mathrm{OH}$ & I & $\mathrm{H}$ & $\mathrm{Me}$ & $2 \cdot 025$ & $2 \cdot 201$ & $2 \cdot 225$ \\
\hline 10 & $\mathrm{O}$ & $\mathrm{CH}_{2} \mathrm{CH}_{2} \mathrm{OH}$ & $\mathrm{OH}$ & $\mathrm{H}$ & $\mathrm{Me}$ & $2 \cdot 230$ & $2 \cdot 516$ & $2 \cdot 483$ \\
\hline 11 & $\mathrm{O}$ & $\mathrm{CH}_{2} \mathrm{CH}_{2} \mathrm{OH}$ & $\mathrm{Me}$ & $\mathrm{Me}$ & $\mathrm{Me}$ & $2 \cdot 649$ & $2 \cdot 500$ & 2.539 \\
\hline 12 & $\mathrm{O}$ & $\mathrm{CH}_{2} \mathrm{CH}_{2} \mathrm{OH}$ & $\mathrm{Me}$ & $\mathrm{Me}$ & $\mathrm{Me}$ & $2 \cdot 386$ & $2 \cdot 329$ & $2 \cdot 331$ \\
\hline 13 & $\mathrm{O}$ & $\mathrm{CH}_{2} \mathrm{CH}_{2} \mathrm{OH}$ & COOMe & $\mathrm{H}$ & $\mathrm{Me}$ & $2 \cdot 114$ & 1.875 & $2 \cdot 042$ \\
\hline 14 & $\mathrm{O}$ & $\mathrm{CH}_{2} \mathrm{CH}_{2} \mathrm{OH}$ & COMe & $\mathrm{H}$ & $\mathrm{Me}$ & $2 \cdot 236$ & $2 \cdot 212$ & $2 \cdot 272$ \\
\hline 15 & $\mathrm{O}$ & $\mathrm{CH}_{2} \mathrm{CH}_{2} \mathrm{OH}$ & $\mathrm{COOH}$ & $\mathrm{H}$ & $\mathrm{Me}$ & $2 \cdot 344$ & $2 \cdot 255$ & $2 \cdot 266$ \\
\hline 16 & $\mathrm{O}$ & $\mathrm{CH}_{2} \mathrm{CH}_{2} \mathrm{OH}$ & $\mathrm{CN}$ & $\mathrm{H}$ & $\mathrm{Me}$ & $2 \cdot 358$ & $2 \cdot 372$ & $2 \cdot 345$ \\
\hline 17 & $\mathrm{O}$ & $\mathrm{CH}_{2} \mathrm{CH}_{2} \mathrm{OH}$ & $\mathrm{H}$ & $\mathrm{H}$ & Allyl & $2 \cdot 547$ & $2 \cdot 375$ & $2 \cdot 396$ \\
\hline 18 & $\mathrm{~S}$ & $\mathrm{CH}_{2} \mathrm{CH}_{2} \mathrm{OH}$ & $\mathrm{H}$ & $\mathrm{H}$ & $\mathrm{Et}$ & $2 \cdot 369$ & $2 \cdot 328$ & $2 \cdot 408$ \\
\hline 19 & $\mathrm{~S}$ & $\mathrm{CH}_{2} \mathrm{CH}_{2} \mathrm{OH}$ & $\mathrm{H}$ & $\mathrm{H}$ & $\operatorname{Pr}$ & $2 \cdot 262$ & $2 \cdot 415$ & $2 \cdot 402$ \\
\hline 20 & $\mathrm{~S}$ & $\mathrm{CH}_{2} \mathrm{CH}_{2} \mathrm{OH}$ & $\mathrm{ME}$ & $\mathrm{Me}$ & $i-\operatorname{Pr}$ & $2 \cdot 170$ & $2 \cdot 355$ & $2 \cdot 391$ \\
\hline 21 & $\mathrm{~S}$ & $\mathrm{CH}_{2} \mathrm{CH}_{2} \mathrm{OH}$ & $\mathrm{Cl}$ & $\mathrm{Cl}$ & Et & $2 \cdot 362$ & $2 \cdot 245$ & $2 \cdot 246$ \\
\hline 22 & $\mathrm{O}$ & $\mathrm{CH}_{2} \mathrm{CH}_{2} \mathrm{OH}$ & $\mathrm{H}$ & $\mathrm{H}$ & Et & 1.716 & $2 \cdot 025$ & $2 \cdot 010$ \\
\hline 23 & $\mathrm{O}$ & $\mathrm{CH}_{2} \mathrm{CH}_{2} \mathrm{OH}$ & $\mathrm{H}$ & $\mathrm{H}$ & $\operatorname{Pr}$ & 1.806 & 1.988 & $2 \cdot 000$ \\
\hline 24 & $\mathrm{O}$ & $\mathrm{CH}_{2} \mathrm{CH}_{2} \mathrm{OH}$ & $\mathrm{H}$ & $\mathrm{H}$ & $i-\operatorname{Pr}$ & $2 \cdot 602$ & $2 \cdot 438$ & $2 \cdot 433$ \\
\hline 25 & $\mathrm{O}$ & $\mathrm{CH}_{2} \mathrm{CH}_{2} \mathrm{OH}$ & $\mathrm{Me}$ & $\mathrm{Me}$ & Et & $2 \cdot 387$ & $2 \cdot 328$ & $2 \cdot 288$ \\
\hline 26 & $\mathrm{O}$ & $\mathrm{CH}_{2} \mathrm{CH}_{2} \mathrm{OH}$ & $\mathrm{Me}$ & $\mathrm{Me}$ & $i-\operatorname{Pr}$ & $2 \cdot 364$ & $2 \cdot 328$ & $2 \cdot 309$ \\
\hline 27 & $\mathrm{O}$ & $\mathrm{CH}_{2} \mathrm{CH}_{2} \mathrm{OH}$ & $\mathrm{Cl}$ & $\mathrm{Cl}$ & Et & $2 \cdot 173$ & $2 \cdot 219$ & $2 \cdot 176$ \\
\hline 28 & $\mathrm{O}$ & $\mathrm{CH}_{2} \mathrm{CH}_{2} \mathrm{OH}$ & $\mathrm{H}$ & $\mathrm{H}$ & $\mathrm{H}$ & $2 \cdot 107$ & $2 \cdot 108$ & $2 \cdot 053$ \\
\hline 29 & $\mathrm{O}$ & $\mathrm{CH}_{2} \mathrm{CH}_{2} \mathrm{OnC}_{5} \mathrm{H}_{11}$ & $\mathrm{H}$ & $\mathrm{H}$ & $\mathrm{Me}$ & $2 \cdot 871$ & $2 \cdot 658$ & $2 \cdot 732$ \\
\hline 30 & $\mathrm{O}$ & $\mathrm{CH}_{2} \mathrm{CH}_{2} \mathrm{OCH}_{2} \mathrm{Ph}$ & $\mathrm{H}$ & $\mathrm{H}$ & $\mathrm{Me}$ & 1.740 & $1 \cdot 561$ & 1.608 \\
\hline 31 & $\mathrm{O}$ & $\mathrm{Me}$ & $\mathrm{H}$ & $\mathrm{H}$ & $\mathrm{Me}$ & 1.653 & $1 \cdot 491$ & 1.739 \\
\hline 32 & $\mathrm{O}$ & $\mathrm{Et}$ & $\mathrm{H}$ & $\mathrm{H}$ & $\mathrm{Me}$ & $2 \cdot 387$ & $2 \cdot 282$ & $2 \cdot 357$ \\
\hline 33 & $\mathrm{O}$ & $\operatorname{Pr}$ & $\mathrm{H}$ & $\mathrm{H}$ & $\mathrm{Me}$ & $2 \cdot 364$ & $2 \cdot 172$ & $2 \cdot 197$ \\
\hline 34 & $\mathrm{O}$ & $\mathrm{Bu}$ & $\mathrm{H}$ & $\mathrm{H}$ & $\mathrm{Me}$ & $2 \cdot 167$ & $2 \cdot 092$ & $2 \cdot 068$ \\
\hline 35 & $\mathrm{O}$ & $\mathrm{CH}_{2} \mathrm{Ph}$ & $\mathrm{H}$ & $\mathrm{H}$ & $\mathrm{Me}$ & 1.919 & 1.951 & 1.908 \\
\hline 36 & $\mathrm{~S}$ & $\mathrm{Et}$ & $\mathrm{H}$ & $\mathrm{H}$ & $\mathrm{Et}$ & 1.978 & 1.770 & 1.891 \\
\hline 37 & $\mathrm{~S}$ & $\mathrm{Et}$ & $\mathrm{Cl}$ & $\mathrm{Cl}$ & Et & 1.908 & 1.978 & 1.999 \\
\hline 38 & $\mathrm{O}$ & $\mathrm{Et}$ & $\mathrm{H}$ & $\mathrm{H}$ & Et & 1.653 & $1 \cdot 611$ & 1.609 \\
\hline 39 & $\mathrm{O}$ & Et & $\mathrm{Cl}$ & $\mathrm{Cl}$ & $\mathrm{Et}$ & 1.663 & 1.942 & 1.885 \\
\hline 40 & $\mathrm{O}$ & $i-\operatorname{Pr}$ & $\mathrm{H}$ & $\mathrm{H}$ & Et & $2 \cdot 207$ & $2 \cdot 061$ & $2 \cdot 042$ \\
\hline 41 & $\mathrm{O}$ & $\mathrm{CH}_{2} \mathrm{Ph}$ & $\mathrm{H}$ & $\mathrm{H}$ & Et & 1.653 & 1.691 & 1.651 \\
\hline 42 & $\mathrm{O}$ & $\mathrm{CH}_{2} \mathrm{CH}_{2} \mathrm{Ph}$ & $\mathrm{H}$ & $\mathrm{H}$ & Et & $2 \cdot 155$ & 1.951 & 1.916 \\
\hline 43 & $\mathrm{O}$ & Et & $\mathrm{H}$ & $\mathrm{H}$ & $i-\operatorname{Pr}$ & $1 \cdot 230$ & 1.583 & $1 \cdot 355$ \\
\hline 44 & $\mathrm{O}$ & $\mathrm{Et}$ & $\mathrm{H}$ & $\mathrm{H}$ & $i-\operatorname{Pr}$ & 1.531 & 1.659 & 1.739 \\
\hline 45 & $\mathrm{O}$ & $\mathrm{R}^{\prime}=\mathrm{H}$ & $\mathrm{H}$ & $\mathrm{H}$ & $\mathrm{Me}$ & $1 \cdot 580$ & $1 \cdot 549$ & 1.418 \\
\hline 46 & $\mathrm{O}$ & $\mathrm{R}^{\mathrm{l}}=\mathrm{Me}$ & $\mathrm{H}$ & $\mathrm{H}$ & $\mathrm{Me}$ & $2 \cdot 025$ & 1.925 & 1.905 \\
\hline 47 & $\mathrm{O}$ & $\mathrm{R}^{\prime}=\mathrm{Et}$ & $\mathrm{H}$ & $\mathrm{H}$ & $\mathrm{Me}$ & $2 \cdot 398$ & $2 \cdot 567$ & $2 \cdot 671$ \\
\hline 48 & $\mathrm{O}$ & $\mathrm{R}^{\mathrm{l}=\mathrm{u}}$ & $\mathrm{H}$ & $\mathrm{H}$ & $\mathrm{Me}$ & 1.949 & $2 \cdot 322$ & $2 \cdot 198$ \\
\hline
\end{tabular}


<smiles></smiles>

Figure 1. HEPT analogues used in the present study.

\subsection{Regression analysis}

We have used the maximum $\mathrm{R}^{2}$ improvement as well as leave-one-out methods to identify prediction models. ${ }^{17-19}$ When using the latter, there is no need to divide the compounds into training and test sets. The method of maximum $\mathrm{R}^{2}$ finds the "best" one variable model, the "best" two variable model and so forth for the prediction of property/activity. Several models (combinations of variables) were examined to identify combinations of variables with good prediction capabilities. In all regression models developed, we have examined a variety of statistics associated with residues, i.e. the Wilks-Shapiro test for normality and Cooks D-statistics for outliers, to obtain the most reliable results. ${ }^{18,19}$ Finally, we have used leave-one-out method and cross-validation for the investigation of the predictive power of the proposed models. ${ }^{18-20}$

Multiple regression analyses for correlating antiHIV activities of the present set of compounds with the aforementioned molecular descriptors were carried out using Regress-1 software as supplied by Professor I Lukovits, Hungarian Academy of Sciences, Budapest. Several multiple regressions were attempted using the correlation matrix from this program and the best results are considered and discussed in developing QSAR and, hence, for modelling the anti-HIV activities of the compounds in the present study.

\subsection{Indicator parameters $\left(I p_{1}, I p_{2}, I p_{3}\right)$}

The indicator parameters ${ }^{18,21}$ (variables) take on only two values, usually zero and one. The two values signify that the observation falls in one of two possible categories. The numerical values of the dummy variables are not intended to reflect a quantitative ordering of categories, but only serve to identify category or class membership. Therefore, they show the significance of a particular group or a substituent in a given series of drug. They account for the abrupt increase or decrease of a given pharmacological activity at any specific site in the drug molecule. If the coefficient of indicator parameter carries a negative sign in the regression expression, this makes it very clear that the compound having this particular group at a particular position has considerably lower potency.

In the present case, the indicator parameter $I p_{\mathrm{I}}$ is taken as 1 when the $-\mathrm{CH}_{2} \mathrm{CH}_{2} \mathrm{OH}$ moiety is present at $\mathrm{R}^{1}$ otherwise it is zero. When halogen is present at $\mathrm{R}^{2}$ then indicator parameter $I p_{2}$ is used whose value is taken as unity. For the presence of Me at $R^{4}$ the indicator parameter used is $I p_{3}$ whose value is taken as unity.

\subsection{Equalized electronegativity $\left(\chi_{e q}\right)$}

The equalized electronegativity $\left(\chi_{\mathrm{eq}}\right)^{11-15}$ has been calculated using the formula,

$$
\chi_{\mathrm{eq}}=N / \sum v / x,
$$

where, $N=\sum v=$ total no. of atoms in the species, $v=$ no. of atoms of a particular element in the species, and, $x=$ electronegativity of that particular element. whereas, group electronegativity is defined as,

$$
X_{\mathrm{G}}=N_{\mathrm{G}} /(v / x),
$$

where $N_{\mathrm{G}}=$ no. of atoms in the group formula.

\section{5 van der Waals volume $(V w)$}

The van der Waals volumes of the various compounds used in the present study have been calculated using the method suggested by Morriguchi et $a l^{16}$.

\section{Results and discussion}

Table 1 records the structural details of RT-inhibitors under present study. This table 1 also records observed and estimated values of cytotoxicity in $p C C_{50}$ units. The calculated molecular descriptors $\left(\chi_{\text {eq }}, V w\right)$ and assumed indicator parameters $\left(I p_{1}, I p_{2}\right.$, $\left.I p_{3}\right)$ are presented in table 2.

The most straightforward way to perform QSAR analysis is to divide the set of molecules into training set and test set. We obtain the QSAR equations using the training set and then apply them on the 
test set. Such an analysis clearly gauges the reliability of QSAR equations. However, if leave-one-out methodology is used and then cross-validation is done, there is no need for such division into training and test sets.

Table 2. Molecular descriptors of compounds used in the present study (see table 1).

\begin{tabular}{|c|c|c|c|c|c|}
\hline $\begin{array}{l}\text { Compd. } \\
\text { No }\end{array}$ & $\chi_{\text {eq }}$ & $V w$ & $I p_{1}$ & $I p_{2}$ & $I p_{3}$ \\
\hline 1 & $2 \cdot 3839$ & $2 \cdot 667$ & 1 & 0 & 1 \\
\hline 2 & $2 \cdot 3716$ & $2 \cdot 822$ & 1 & 0 & 1 \\
\hline 3 & $2 \cdot 3516$ & $3 \cdot 129$ & 1 & 0 & 1 \\
\hline 4 & $2 \cdot 4025$ & $2 \cdot 620$ & 1 & 0 & 1 \\
\hline 5 & $2 \cdot 4844$ & $2 \cdot 805$ & 1 & 0 & 1 \\
\hline 6 & $2 \cdot 4342$ & 2.650 & 1 & 0 & 1 \\
\hline 7 & $2 \cdot 4052$ & 2.687 & 1 & 0 & 1 \\
\hline 8 & $2 \cdot 4171$ & $2 \cdot 720$ & 1 & 0 & 1 \\
\hline 9 & $2 \cdot 3794$ & $2 \cdot 817$ & 1 & 0 & 1 \\
\hline 10 & $2 \cdot 4896$ & $2 \cdot 582$ & 1 & 0 & 1 \\
\hline 11 & $2 \cdot 3716$ & $2 \cdot 820$ & 1 & 0 & 1 \\
\hline 12 & $2 \cdot 3566$ & $2 \cdot 983$ & 1 & 0 & 1 \\
\hline 13 & $2 \cdot 4223$ & $2 \cdot 923$ & 1 & 0 & 1 \\
\hline 14 & $2 \cdot 4048$ & $2 \cdot 761$ & 1 & 0 & 1 \\
\hline 15 & $2 \cdot 4391$ & $2 \cdot 756$ & 1 & 0 & 1 \\
\hline 16 & $2 \cdot 4228$ & $2 \cdot 822$ & 1 & 0 & 1 \\
\hline 17 & $2 \cdot 3866$ & $2 \cdot 700$ & 1 & 0 & 0 \\
\hline 18 & $2 \cdot 3677$ & $2 \cdot 784$ & 1 & 0 & 0 \\
\hline 19 & $2 \cdot 3566$ & $2 \cdot 938$ & 1 & 0 & 0 \\
\hline 20 & $2 \cdot 3387$ & $3 \cdot 244$ & 1 & 0 & 0 \\
\hline 21 & $2 \cdot 4083$ & $3 \cdot 114$ & 1 & 1 & 0 \\
\hline 22 & $2 \cdot 3838$ & $2 \cdot 668$ & 1 & 0 & 0 \\
\hline 23 & $2 \cdot 3715$ & $2 \cdot 822$ & 1 & 0 & 0 \\
\hline 24 & $2 \cdot 3715$ & $2 \cdot 822$ & 1 & 0 & 0 \\
\hline 25 & $2 \cdot 3609$ & $2 \cdot 974$ & 1 & 0 & 0 \\
\hline 26 & $2 \cdot 3516$ & $3 \cdot 128$ & 1 & 0 & 0 \\
\hline 27 & $2 \cdot 4252$ & $2 \cdot 998$ & 1 & 1 & 0 \\
\hline 28 & $2 \cdot 4158$ & $2 \cdot 361$ & 1 & 0 & 0 \\
\hline 29 & $2 \cdot 3436$ & $3 \cdot 297$ & 0 & 0 & 1 \\
\hline 30 & $2 \cdot 3714$ & $3 \cdot 395$ & 0 & 0 & 1 \\
\hline 31 & $2 \cdot 3932$ & $2 \cdot 292$ & 0 & 0 & 1 \\
\hline 32 & $2 \cdot 3690$ & $2 \cdot 446$ & 0 & 0 & 1 \\
\hline 33 & $2 \cdot 3644$ & 2.557 & 0 & 0 & 1 \\
\hline 34 & $2 \cdot 3534$ & $2 \cdot 754$ & 0 & 0 & 1 \\
\hline 35 & $2 \cdot 3764$ & 3.006 & 0 & 0 & 1 \\
\hline 36 & $2 \cdot 3445$ & $2 \cdot 716$ & 0 & 0 & 0 \\
\hline 37 & $2 \cdot 3894$ & $3 \cdot 046$ & 0 & 1 & 0 \\
\hline 38 & $2 \cdot 3644$ & $2 \cdot 600$ & 0 & 0 & 0 \\
\hline 39 & $2 \cdot 4062$ & $2 \cdot 930$ & 0 & 1 & 0 \\
\hline 40 & $2 \cdot 3534$ & $2 \cdot 754$ & 0 & 0 & 0 \\
\hline 41 & $2 \cdot 3655$ & $3 \cdot 160$ & 0 & 0 & 0 \\
\hline 42 & $2 \cdot 3558$ & $3 \cdot 314$ & 0 & 0 & 0 \\
\hline 43 & $2 \cdot 3534$ & $2 \cdot 790$ & 0 & 0 & 0 \\
\hline 44 & $2 \cdot 3677$ & 2.650 & 0 & 0 & 0 \\
\hline 45 & $2 \cdot 4078$ & 1.895 & 0 & 1 & 0 \\
\hline 46 & $2 \cdot 3866$ & $2 \cdot 057$ & 0 & 1 & 0 \\
\hline 47 & $2 \cdot 3698$ & $2 \cdot 211$ & 0 & 1 & 0 \\
\hline 48 & $2 \cdot 3445$ & $2 \cdot 237$ & 0 & 1 & 0 \\
\hline
\end{tabular}

The first step in proposing significant models is the selection of descriptors. This is achieved by obtaining correlation matrix as shown in table 3. The descriptors selected are those which exhibit correlation coefficient inferior to 0.5 and lead to high $F$ value during automatic linear regression modelling when processing the data corresponding to the 48 compounds used.

The inspection of the correlation matrix (table 3) indicates that none of the molecular descriptors used independently correlate significantly with $p C C_{50}$. The data, however, show that $V w$ is a better parameter for use in the regression analyses for obtaining statistically significant models.

Preliminary regression analysis has shown the non-existence of statistically significant mono-parametric models. This shows that statistically significant models are only possible through multiple regression analysis. The statistically significant multiparametric models obtained are presented in table 4 . The regression parameters and the quality of correlations of these models are given in table 5 .

A perusal of tables 4 and 5 show that the performance of various 2, 3 and 4 parametric regression models shed much light on structure-activity relationships. Indicator parameters $I p_{1}$ and $I p_{2}$ play dominant roles in the exhibition of cytotoxic activity $\left(p C C_{50}\right)$ of the HIV-inhibitors used. In view of this, we fix upon two such models (models 3 and 4, refer tables 4 and 5). These models are tri- and tetra-parametric respectively as given by the following,

$$
\begin{aligned}
& p C C_{50}=-3.9261+0.7173( \pm 0.0836) V w \\
& \quad-\left(0.4259( \pm 0.0509) I p_{1}+0.1303( \pm 0.0643) I p_{2},\right.
\end{aligned}
$$

$n=48, \quad S e=0.1700, \quad R=0.8750, \quad F=47.912, \quad Q=$ $5 \cdot 1470$.

$$
\begin{aligned}
& p C C_{50}=-0.2116+0.6741( \pm 0.0832) V w-1.4878 \\
& ( \pm 0.7151)) \chi_{\text {eq }}-0.3931 \\
& \quad \pm 0.0670) I p_{2},
\end{aligned}
$$

$n=48, \quad S e=0.1639, \quad R=0.8872, \quad F=39.730, \quad Q=$ 5.4130 .

The van der Waals volume $(V w)$ is a steric parameter, its coefficient is positive in both the models. The positive value of $V w$ shows that $p C C_{50}$ depends on the size of the fragments attached at $\mathrm{R}^{1}, \mathrm{R}^{2}, \mathrm{R}^{4}$ and $X$. It can thus be stated that increase in the 
Table 3. Correlation matrix showing inter-correlation of molecular descriptors and their correlation with activity.

\begin{tabular}{lrrrrrrr}
\hline & \multicolumn{1}{c}{$\chi_{\mathrm{eq}}$} & $V w$ & $p C C_{50}$ & $I p_{1}$ & $I p_{2}$ & $I p_{3}$ & $I p_{4}$ \\
\hline$\chi_{\mathrm{eq}}$ & 1.0000 & & & & & & \\
$V w$ & -0.1659 & 1.0000 & & & & & \\
$p C C_{50}$ & -0.3782 & 0.6252 & 1.0000 & & & & \\
$I p_{1}$ & 0.3315 & 0.0410 & -0.5679 & 1.0000 & & & \\
$I p_{2}$ & 0.3795 & 0.1256 & 0.1250 & 0.1706 & 1.0000 & & \\
$I p_{3}$ & -0.4911 & 0.2496 & 0.3116 & $-0 \cdot 1449$ & -0.1009 & 1.0000 & \\
$I p_{4}$ & 0.3819 & -0.2006 & -0.2657 & -0.0191 & -0.0716 & 0.3944 & 1.0000 \\
\hline
\end{tabular}

Table 4. Statistically significant QSAR models for HIV-reverse transcriptase.

\begin{tabular}{ll}
\hline Model no. & Regression expressions \\
\hline$(1)$ & $p C C_{50}=-4.1386+0.7100( \pm 0.1307) V w$ \\
$(2)$ & $p C C_{50}=-3.9695+0.7377( \pm 0.0858) V w-0.4086( \pm 0.0519) I p_{1}$ \\
$(3)$ & $p C C_{50}=-3.9261+0.7173( \pm 0.0836) V w-\left(0.4259( \pm 0.0509) I p_{1}+\right.$ \\
& $0.1303( \pm 0.0643) I p_{2}$ \\
$(4)$ & $\left.p C C_{50}=-0.2116+0.6741( \pm 0.0832) V w-1.4878( \pm 0.7151)\right) \chi_{\text {eq }}-$ \\
& $0.3931( \pm 0.0516) I p_{1}+0.1833( \pm 0.0670) I p_{2}$ \\
\hline
\end{tabular}

Table 5. Quality of the models given in table 4.

\begin{tabular}{|c|c|c|c|c|c|c|}
\hline $\begin{array}{l}\text { Model } \\
\text { no }\end{array}$ & $\begin{array}{c}\text { No. of } \\
\text { parameters }\end{array}$ & $\mathrm{Se}$ & $R^{2}$ & $R$ & $F$ & $Q$ \\
\hline 1 & 1 & $0 \cdot 2680$ & $0 \cdot 3990$ & 0.6252 & $29 \cdot 524$ & $2 \cdot 3320$ \\
\hline 2 & 2 & 0.1758 & 0.7437 & 0.8624 & $65 \cdot 295$ & 4.9056 \\
\hline 3 & 3 & $0 \cdot 1700$ & 0.7656 & 0.8750 & $47 \cdot 912$ & $5 \cdot 1470$ \\
\hline 4 & 4 & 0.1639 & 0.7871 & 0.8872 & 39.730 & 5.4130 \\
\hline
\end{tabular}

$R$ - correlation coefficient, $F-F$-ratio, $Q-$ quality factor ${ }^{16}(Q=R / S e)$

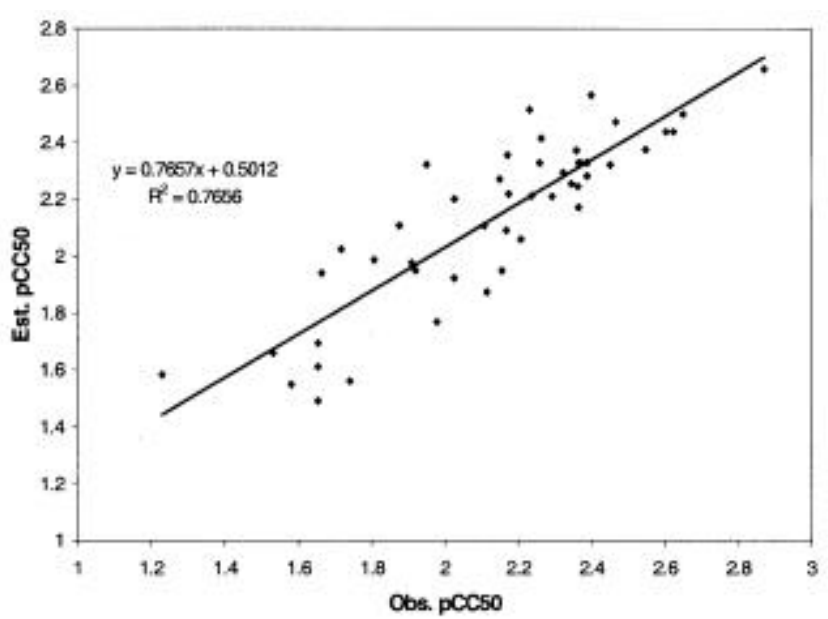

Figure 2. Correlation between observed and estimated $p C C_{50}$ using model 3 (table 1 ).

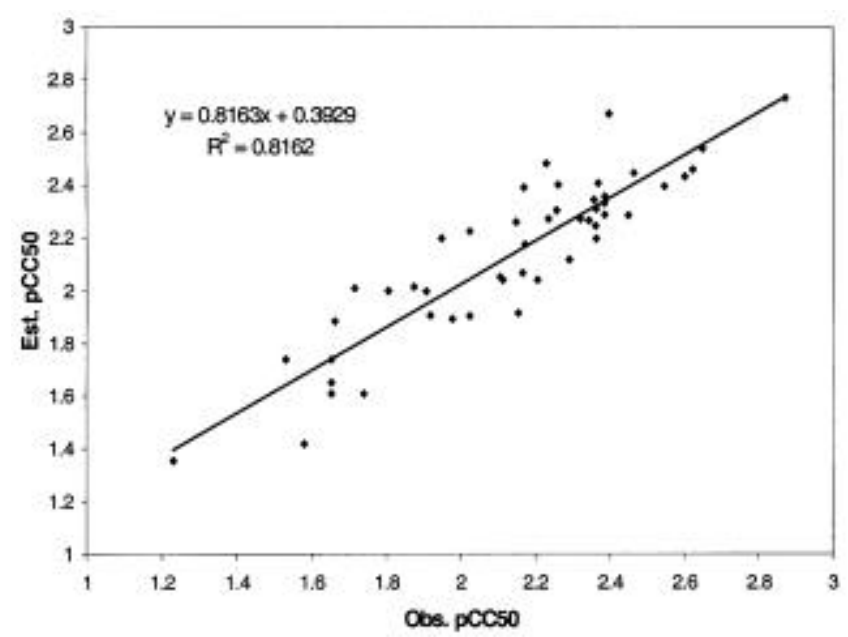

Figure 3. Correlation between observed and estimated $p C C_{50}$ using model 4 (table 1 ). 
Table 6. Cross-validation parameters ${ }^{4-18}$ for the proposed models (table 4).

\begin{tabular}{lcccccccc}
\hline $\begin{array}{l}\text { Model } \\
\text { no }\end{array}$ & $\begin{array}{c}\text { No. of } \\
\text { parameters }\end{array}$ & Samples & PRESS & SSY & SSY & $r_{\mathrm{cv}}^{2}$ & $S_{\text {PRESS }}$ & PSE \\
\hline 2 & 2 & 48 & 1.3902 & 4.0343 & 0.3446 & 0.6554 & $0 \cdot 1758$ & 0.1702 \\
3 & 3 & 48 & 1.2713 & 4.1531 & 0.3061 & 0.6939 & $0 \cdot 1699$ & 0.1627 \\
4 & 4 & 48 & $1 \cdot 1551$ & 4.2694 & 0.2706 & 0.7295 & $0 \cdot 1639$ & $0 \cdot 1551$ \\
\hline
\end{tabular}

PRESS - predicted residual sum of squares, SSY - sum of the squares of regression value, $r_{\mathrm{cv}}^{2}$-cross-validation correlation coefficient, $S_{\text {PRESS }}$ - uncertainty of prediction, PSEpredictive square error

bulk of the compounds likewise increase $p C C_{50}$. That is, for a compound to become a potent inhibitor $\mathrm{R}^{1}, \mathrm{R}^{2}, \mathrm{R}^{4}$ and $\mathrm{X}$ positions should be occupied by bulky groups. Also, the magnitude of quality factor $(Q)^{22-24}$ indicates that the model expressed by (4) has better predictive potential.

Again, in the above models the indicator parameters, $I p_{1}$ and $I p_{2}$ are present. The former indicator parameter $I p_{1}$ has a negative coefficient and is used when the $-\mathrm{CH}_{2} \mathrm{CH}_{2} \mathrm{OH}$ moiety is present at $\mathrm{R}^{1}$ and the latter $\left(I p_{2}\right)$ has a coefficient which is positive and is used for the presence of halogen at $\mathrm{R}_{2}$. Hence, presence of $-\mathrm{CH}_{2} \mathrm{CH}_{2} \mathrm{OH}$ is not helpful in exhibition of favourable cytotoxic activity $\left(p C C_{50}\right)$.

The data presented in tables 4 and 5 also indicate that the quality of model 4 improves on introduction of an additional parameter, $\chi_{\text {eq }}$, the coefficient of which is negative.

This indicates that introduction of electron-withdrawing groups at $\mathrm{R}^{1}, \mathrm{R}^{2}$ and $\mathrm{R}^{4}$ result in decrease in $p C C_{50}$ value. Thus, highly electronegative groups at these positions are not preferred as it would inhibit the activity.

The predictive potential of the proposed models is determined by employing cross-validation method ${ }^{14,15}$, and the cross-validation parameters estimated for the five proposed models are given in table 6. For the reasons given below these parameters suggest that both the models 3 and 4, (3) and (4) have better predictive potentials compared to others.

To be a reasonable QSAR model, PRESS/SSY should be the smaller than 0.4 , and the value of this ratio smaller than $0 \cdot 1$ indicates an excellent model. ${ }^{18}$ In the present case, except for models 1 and 4, all have this ratio smaller than 0.4.

It is interesting to record that the value of $S_{\text {PRESS }}$ in the present case are very close to that of standard error of estimation, $\mathrm{Se}$. Hence, both these parameters carry the same meaning and $S_{\text {PRESS }}$ does not give any additional information regarding the uncertainty of prediction. In view of this, we have calculated predictive square error, $\mathrm{PSE},{ }^{18}$ as it seems to be most directly related to the uncertainty of prediction. The value of PSE (table 6) is found smallest for model 4 indicating that this model has the highest predictive potential.

Further confirmation of the predictive potential of the proposed models (3) and (4) is obtained by estimating predictive correlation coefficient. The $R_{\text {pred }}^{2}=$ 0.7656 (figure 2) and 0.8162 (figure 3) obtained for models 3 and 4 , indicate that model 4 has the highest predictive potential.

\section{Conclusions}

On the basis of the above discussions we can draw the following conclusions:

(i) van der Waals volume $(V w)$ and equalized electronegativity $\left(\chi_{\mathrm{eq}}\right)$ are good parameters for modelling the cytotoxic activity $\left(p C C_{50}\right)$ of the present set of compounds.

(ii) The introduction of electron-withdrawing groups at $\mathrm{R}^{2}$ and $\mathrm{R}^{4}$ results in decrease in cytotoxic activity $\left(p C C_{50}\right)$. Thus, highly electronegative groups at these positions are not preferred.

\section{Acknowledgements}

We thank Prof I Lukovits for providing Regress-1 software. Two of us (VKA and RS) thank the University Grants Commission, New Delhi for financial support. PVK thanks Prof. Ivan Gutman for introducing him to the fascinating field of chemical topology and graph theory.

\section{References}

1. Rizzo C R, Tirado-Rives J and Jorgensen W L 2001 J. Med. Chem. 44145 
2. Yadav A and Singh S K 2003 Bioorg. Med. Chem. 11 1801

3. Kavcher W and Devillers J (eds) 1990 Practical applications of quantitative structure-activity relationships (QSAR) in environmental chemistry and toxicology (Dordrect: Kluwer Academic)

4. Khadikar P V, Phadnis A and Shrivastava A 2002 Bioorg. Med. Chem. 101181

5. Khadikar P V, Karmarkar S, Singh S and Shrivastava A 2002 Bioorg. Med. Chem. 103163

6. Agrawal V K and Khadikar P V 2002 Bioorg. Med. Chem. 103517

7. Karmarkar S, Agrawal V K, Mathur K C and Khadikar P V 2000 Bulg. Chem. Ind. 7399

8. Karmarkar S, Agrawal V K and Khadikar P V 2003 Sci. Cult. 6916

9. Diudea M V (ed.) 2000 QSPR/QSAR studies by molecular descriptors (Cluj, Romania: Babes-Bolyai University)

10. Khadikar $\mathrm{P}$ V, Mathur $\mathrm{K} \mathrm{C}$, Singh $\mathrm{S}$, Phadnis A, Shrivastava A and Mandloi M 2002 Bioorg. Med. Chem. 101761

11. Khadikar P V, Lukovits I, Agrawal V K, Shrivastava S, Jaiswal M, Gutman I, Karmarkar S and Srivastava A 2003 Indian J. Chem. A42 1436
12. Agrawal V K, Sohgaura R and Khadikar P V 2001 Bioorg. Med. Chem. 93295

13. Agrawal V K, Mishra K and Khadikar P V 2003 Oxid. Commun. 2614

14. Pauling L 1969 The nature of the chemical bond (Ithaca, NY: Cornell Univ. Press)

15. Wells P R 1968 Progress in physical organic chemistry (New York: Interscience) vol. 6

16. Moriguchi I, Kanda Y and Komatsu K 1976 Chem. Pharm. Bull. 241799

17. Tronchet J M J, Grigorov M, Dolatshahi N, Moriand F and Weber 1997 J. Euro. J. Med. Chem. 32279

18. Chaterjee S, Hadi S and Price B 2000 Regression analysis by examples 3rd edn (New York: Wiley)

19. Box G E B, Hunter W G and Hunter J S 1978 Statistics for experiments (New York: Wiley)

20. Lucic B and Trinajstic N 1999 J. Chem. Inf. Comput. Sci. 39121,610

21. Trinajstic N 1992 Chemical graph theory 2nd edn (Boca Raton, FL: CRC Press)

22. Pogliani L 1994 Amino Acids 6141

23. Agrawal V K, Srivastava, R C and Khadikar P V 2001 Acta Pharm. 51117

24. Agrawal V K and Khadikar P V 2002 Oxid. Commun. 25184 